\title{
Perfiles
}

Luis Alvarenga

\section{María Zambrano y Susan Sontag}

2004 fue el año del primer centenario de natalicio de la filósofa española María Zambrano. También fue el año del fallecimiento de la escritora y periodista estadounidense Susan Sontag. Dedicamos estas líneas a repasar la trayectoria de estas dos mujeres que sentaron un importante precedente de honestidad intelectual y compromiso humano.

\section{I}

Nacida en 1904 y fallecida en 1991, la vida de María Zambrano atestigua una época de crisis, tanto para el mundo en general como para España en particular. En lo tocante al país mediterráneo, se trata de la crisis política, social y cultural que concluye con el derrumbe del Imperio español en 1898 , año en que se pierden las úl-

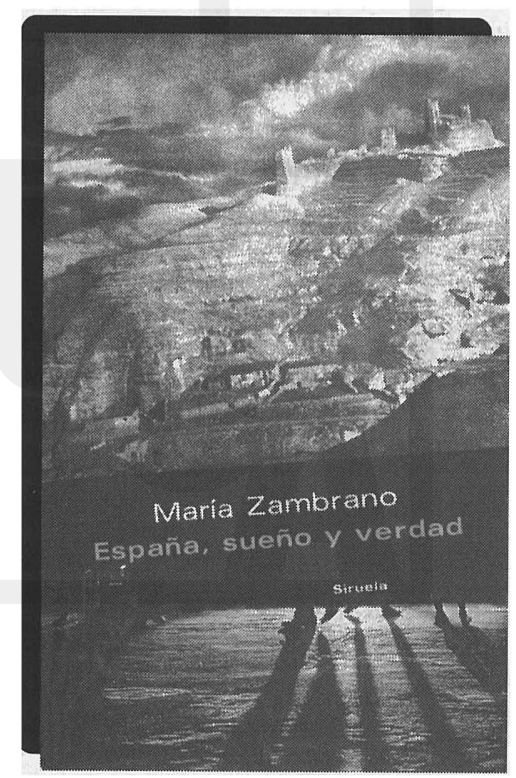


timas colonias de Ultramar: Cuba, Puerto Rico y Filipinas. La etapa de crisis posterior propicia un examen sobre los fundamentos del país y de su cultura, un examen crítico llevado a cabo por dos generaciones de intelectuales: la del 98 y la del 27, una cercana a los restos del naufragio del imperio español; la otra, precursora espiritual de ese intento de superación de la crisis española que fue la Segunda República. Zambrano es heredera de la primera - a través de la influencia intelectual de Miguel de Unamuno, Antonio Machado y su propio padre, Blas Zambrano 1 - y conoce de cerca a la segunda, durante el $d r a-$ ma de España que supuso la Guerra Civil de 1936. La madurez de Zambrano, que transcurre en buena parte en el exilio, culmina con el retorno de España a la democracia tras la muerte de Franco (1975) y con la posterior etapa de consolidación del régimen democrático.

Nacida en Vélez-Málaga en 1904, María Zambrano pasó su infancia en Madrid y Segovia, debido a los traslados que imponía el trabajo docente de don Blas. Éste se ligó a los grupos socialistas (llegó, incluso, a presidir la Agrupación Socialista Obrera, antecedente del Partido Socialista Obrero Español, fundado por el dirigente obrero Pablo Iglesias). Zambrano no heredará tan sólo las inquietu- des políticas del padre, sino también las intelectuales. En 1914, año en que comienza la I Guerra Mundial, escribe y publica un artículo "sobre la suerte de Europa y la paz. El padre se opone, al verlo publicado, a que vuelva a suceder. "Aquí no hay niños prodigios"”.?

La joven Zambrano padece una afección que la aleja durante un tiempo considerable de los libros. $\mathrm{Su}$ posterior ingreso a las aulas universitarias y al estudio de la filosofía, estuvo acompañado de una importante participación política. Fue alumna de José Ortega y Gasset y asistió a los cursos dictados por maestros como Xavier Zubiri - a quien sucedería en la cátedra de Metafísica-y Manuel García Morente. Ortega y Gasset fue, para nuestra autora, un "animador de poderes dormidos, actualizador de secretos, incitador de ocultas posibilidades. De su obra, de su vida, llega una corriente que nos enciende el infinito deseo de ser, en irrefrenable afán de saltar sobre nuestra propia vida y vivirla, profunda, inalienablemente nuestra. La medida de su poder creador está, aparte de los descubrimientos de carácter teórico, en ese contagio de autenticidad que produce". ${ }^{3}$ '

En 1927, María Zambrano se une a la Federación Universitaria Española, movida por la aspiración 
de buscar una "dimensión salvadora de la política". ${ }^{4}$ Esta juvenil inquietud esboza lo que será una preocupación de la autora: buscar que los seres humanos concretos se salven de una historia que los sitúa como sus víctimas, salvación que no es la que prometen las grandes doctrinas políticas presuntamente redentoras. La participación política de María Zambrano privilegió más la reflexión intelectual sobre el activismo político. Lo cual no quiere decir que la joven filósofa no se involucrara en organizaciones como la Liga de Educación Social, encabezada por intelectuales como Ramón Pérez de Ayala y Luis Jiménez de Azúa. Publica su Horizonte del liberalismo, un importante texto en el que enuncia elementos claves de su pensamiento político, a través de la crítica hacia las aporías del liberalismo y hacia el marxismo.

Al proclamarse la II República en 1931, Zambrano se involucra en este importante hecho histórico. "Durante los años de la II República —apunta Julia Castillo-, María Zambrano pertenecía al grupo de escritores, artistas y universitarios que con las Misiones Pedagógicas llevaron a cabo una insólita experiencia de educación popular. En compañía de escritores amigos como Luis Cernuda, Rafael Dieste, J. A. Maravall o el pintor Ramón Gaya, María Zambrano recorrió algunos pueblos y remotas aldeas, llevando hasta sus gentes una imagen de la cultura, de la que por tradición les pertenecía, y de la desconocida (el cine, la pintura, el teatro o la música clásica...)." Ese intento de llevar "una imagen de la cultura" a los pobladores de la España rural es congruente con los planteamientos de Zambrano, que buscan en la tradición artística y literaria española algunos elementos importantes para enfrentar la crisis histórica del país.

La proclamación de la II República es una oportunidad para que España pueda reconocerse, para que pueda "despertar soñándose": "Despertar, sin dejar de soñarnos, sería tener un sueño lúcido. Es el ansia que se padece y que se está a punto de lograr en ciertos momentos de la historia individual o colectiva - cuando un pueblo despierta soñándose, cuando despierta porque su ensueño - su proyecto- se lo exige, le exige conocerse; conocer su pasado, liquidar las amarguras que guarda en su memoria, poner al descubierto las llagas escondidas, realizar una acción que es a la par una confesión, "purificarse", haciendo. En aquellas histórica en que estaba al nacer la República del 14 de abril, los españoles se disponían a hacerlo, a curarse de sus llagas". ${ }^{6}$ 
Durante la Guerra Civil, María Zambrano desarrolla una importante labor, publicando trabajos como Los intelectuales en el drama de España y colaborando en publicaciones progresistas como Cruz y Raya y Hora de España. Se desempeña, además, como Consejero de Propaganda y Consejero Nacional de la Infancia Evacuada en ciudades como Barcelona y Valencia, asediadas como estaban —en 1937- por las tropas de Franco.

Es evidente que las secuelas personales que tuvieron en nuestra autora, tanto la II Guerra Mundial como su prolongado destierro, marcan su pensamiento. La existencia de esa serie de "detalles" que provocan "giros decisivos" en la existencia personal, muestran cuán importante es esa dimensión modesta, íntima, propia de las "minúsculas" vidas personales frente a la dimensión apabullante de los "grandes" acontecimientos. El pensar de María Zambrano rescatará la importancia de esa dimensión "modesta", "ínfima", "débil" de lo que atañe a la persona concreta, frente a la "gran" historia.

Para Zambrano, la etapa de la segunda posguerra mundial no trae consigo la redención de la humanidad, sino todo lo contrario. En sus palabras liminares a Senderos, una compilación de sus escritos publicados durante la Gue- rra Civil española, afirma que el enfrentamiento interno de su país no fue otra cosa que el punto de arranque de una etapa de deshumanización: "Y así, estos artículos escritos en aquel final del año 36 en Santiago de Chile, encaminando tan sólo alguna verdad que de tan diáfana habría sido innecesario decir, me parecen ahora meros signos de un padecer que no hacía más que comenzar. Pues que las razones se mantienen en pie por sí mismas. Y por desventura, el dintel de aquel conflicto entre el hombre que pide vivir y la historia, la antibistoria más bien, que lo condena sigue en pie. No ha habido "progreso" alguno sino en la abismática caída que reitera su amenaza. A los males de la guerra ban sustituido en la fingida paz la tortura declarada y establecida en formas innumerables, la proliferación del horror metódicamente cultivado: la degradación última de la razón occidental que al borror ofrece su método. El método sin un gramo ya de respeto a la inocencia que, eso sí, retoña inagotable con invencible aliento; retoñar, sí, es lo que más cuenta. $\mathrm{Y}$ de la inocencia justamente se trata. De la inocencia indispensable para que la historia sea vivida en forma transparente, para que un soplo inextinguible de verdad las sostenga. La inocencia que fecunda la razón librándola de ser una mera construcción que en su 
caída se degrada en ser un ciego instrumento. $\mathrm{Y}$ en verdad el drama de España nos despertó más que la conciencia a la inocencia, no a la ingenuidad, según ese reiterado reproche que se nos dirige nacido de simpatía". Esto lo escribía Zambrano en 1977. ¿Ha traspasado, después del tan traído y llevado "fin de las ideologías", la humanidad ese dintel que separa la antihistoria de la historia verdaderamente humana?

\section{II}

En un sentido, el empirico o fáctico, la literatura es meramente la suma de todo lo escrito y tenido por literatura. En otro sentido, el ideal, la literatura es la suma de todo lo que mejora, enaltece y bace más necesaria la actividad literaria. En esta segunda y más valiosa acepción, la literatura bonra $-y$ representametas ideales en sentido estricto. Es decir, nunca alcanzadas del todo. Sin embargo, son aún más irresistibles y ejercen mayor autoridad como ideales precisamente porque resulta muy difícil mantenerlos.

Susan Sontag, en su discurso de recepción del Premio Príncipe de Asturias

La estadounidense Susan Sontag fue la conciencia crítica del país más poderoso de la tierra. El oficio de escribir fue la columna vertebral

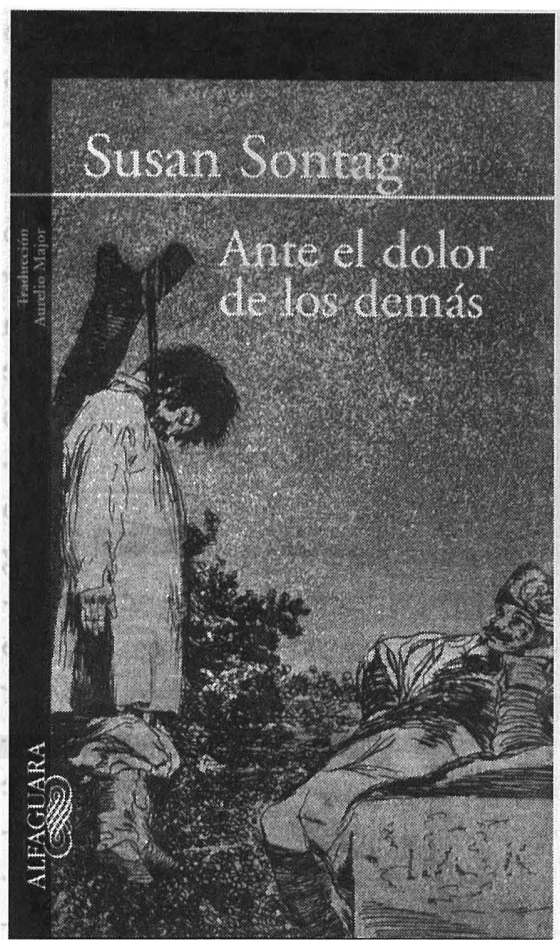

de esta intelectual nacida en una familia judía neoyorquina - como Woody Allen - en 1933 -el mismo año en que vieron la luz las poetas salvadoreñas Irma Lanzas y Mercedes Durand-. Falleció la última semana de diciembre. Su legado tangible lo constituyen novelas como En América y El amante del volcán; los ensayos La enfermedad y sus metáforas, Contra la interpretación, Sobre la fotografía y Ante el dolor de los demás; piezas de teatro, películas como Duet for Cannibals y Brother Carl e innumerables artículos periodísticos. Su herencia impalpable, que es el espíritu que 
movió a la primera, fue el ejercicio de la crítica, en sus más distintas variantes: crítica social, crítica literaria, crítica cultural.

El verbo escrito de Sontag tomó distintas rutas: el ensayo, el cine y el teatro -organizó una puesta en escena de Esperando a Godot, de Samuel Beckett, en una Sarajevo asediada por la muerte-.La polémica acompañó a Sontag, por lo punzante de sus opiniones. Sontag fue, en vida, una referencia obligatoria en las universitarias, pero no tuvo empacho para aparecer fotografiada en un anuncio de vodka Absolut, captada por el lente artístico de Annie Leibovitz. Oscilaba entre el ambiente académico y la cultura de masas. Su ensayo de 1964, Notas sobre lo "camp", rescata los méritos del arte de divulgación masiva y que se produce sin mayores pretensiones intelectuales. Haciendo un juego con algunas citas de Oscar Wilde, Sontag preconiza en ese momento la supremacía de la forma estética sobre el contenido. Dice: "Hacer énfasis en el estilo disminuye el contenido, o introducir una actitud que es neutral con respecto al contenido. Cae por su peso el que la sensibilidad camp no tiene compromisos, es "despolitizada", o, cuando menos, apolítica. No sólo ahí hay una visión camp, una manera camp de ver las cosas. Lo camp es una cua- lidad que podría descubrirse tanto en los objetos como en la conducta de las personas. (...) Para lo camp, el arte es siempre arte decorativo, que hace énfasis en la textura, en la superficie sensual y en el estilo en desmedro del contenido. La música de concierto, puesto que carece de contenido, raras veces es camp. (...) La crítica de cine (como aquella que se expresa en las listas de "Las diez peores películas que he visto") es, probablemente, la gran divulgadora del gusto camp en la actualidad, puesto que la mayoría de las personas siguen yendo al cine animadamente y sin pretensiones". ${ }^{8}$ En ese mismo texto afirma que aquel que insiste en los placeres altos y serios se priva del placer, pues se restringe en lo que puede disfrutar. "El gusto camp (...) hace jovial al hombre de buen gusto, justo en aquel punto en que corría el riesgo de sentirse frustrado crónicamente. Es bueno para la digestión". 'En su libro titulado Contra la interpretación aboga por una experiencia "visceral" del arte, por encima del intelectualismo estético. Ciertamente, son ideas ante las cuales uno no puede ser indiferente. Ideas provocativas, que mueven al debate. Eso es lo que constantemente produjo la escritora norteamericana.

La lente de Sontag abarcó la política de su tiempo. No se mi- 
dió para cuestionar la inteligencia del presidente de su país, ni para defender a Salman Rushdie cuando otros le daban la espalda. Desde las páginas del célebre semanario The New Yorker - del cual fue asidua colaboradora durante décadas-, lanzó estas palabras cuestionadoras, pocos días después de los atentados del 11 de septiembre: "Las voces autorizadas para dar seguimiento a este hecho parecen haberse unido en una campaña para infantilizar al público. ¿En dónde está el reconocimiento de que este no fue un "cobarde" ataque contra la "civilzación", o la "libertad", o el "mundo libre", sino un ataque en contra del autoproclamado súper poder mundial, llevado a cabo como consecuencia de unas determinadas acciones y alianzas de los Estados Unidos? ¿Cuántos ciudadanos están concientes del actual bombardeo estadounidense en Iraq? Y si se utilizará el adjetivo "cobardemente", parece a todas luces más propio para aplicarlo a quienes asesinan desde donde están a salvo de cualquier represalia, en lo alto del cielo, que a aquellos que están dispuestos a perecer para matera a otros. En lo que respecta al valor (una virtud moralmente neutral), puede decirse lo que sea sobre los que perpetraron la matanza del martes, pero no que eran cobardes". ${ }^{10}$
Comprendió que el intelectual debe despojarse de cualquier ambición redentora y cumplir el papel modesto de tábano. Fue una implacable crítica de la política exterior de los EEUU, desde la guerra de Vietnam hasta la guerra de Irak. Sin embargo, justificó la participación de los EEUU en la guerra de los Balcanes, trayendo a cuenta el caso de la guerra de los países aliados contra la Alemania nazi.

Dirigió su mirada crítica también al manejo de las imágenes fotográficas del sufrimiento humano causado por las guerras. En un punzante libro, escrito casi al final de su vida, Ante el dolor de los demás (Alfaguara, México, 2004), desnuda las posibles manipulaciones que se hacen de estas imágenes con fines ideológicos. Las fotografías de las víctimas pueden utilizarse para concienciar a la gente sobre la necesidad de poner fin a las guerras, pero también pueden servir para justificar nuevos derramamientos de sangre. Igualmente, sin hacer concesiones a la ingenuidad, Sontag escribió un artículo titulado Fascinating Fascism, sobre la obra fotográfica y fílmica de Leni Riefenstahl, artista alemana que se puso al servicio del nazismo, rodando películas como El triunfo de la voluntad y Olimpia. En Fascinating 
Fascism, el pasado nazi y los posteriores intentos de la propia Riefenstahl de desmarcarse o de atenuar su colaboración con el régimen hitleriano -alegando sus diferencias con algunos de los jerarcas nazis-, son un pretexto para explorar la estética fascista y la fascinación que, a juicio de Sontag, ésta produce.

Una faceta extraliteraria, que pone de relieve la integridad personal de Sontag, es su lucha contra la enfermedad. Padeció un cáncer durante muchos años, pero se sometió con valentía a las operaciones $\mathrm{y}$, por si fuera poco, redescubrió el gozo de escribir novelas tras varios años de dedicarse al ensayo y al periodismo.

El novelista mexicano Carlos Fuentes la comparó con Erasmo de Rotterdam, encomiando su gran sabiduría. "Erasmo viajaba con treinta y dos volúmenes, que contenían todo aquello que valía la pena conocer. iSusan Sontag lo tiene en su cerebro! No he conocido a otro intelectual que tenga tanta claridad mental, con una capacidad de vincular, de establecer conexiones, de encontrar relacio- nes". Como Terencio, Sontag creyó que nada humano le era ajeno.

\section{Notas}

1. Pedagogo, pensador y fundador de revistas, Blas Zambrano (1874-1938), fue contemporáneo y amigo de Antonio Machado. Sus escritos dan cuenta de la crisis que vive España a finales del XIX y principios del XX.

2. Cfr., de Julia Castillo: "Cronología de María Zambrano", en Antbropos, marzo-abril de 1997, numeros 70-71, pp. 74-75.

3. Citado por Mercedes Martín Luengo en su José Ortega y Gasset, Ediciones Rueda, Madrid, p. 82.

4. "Cronología de María Zambrano", Op. cit., p. 75.

5. Ibid., p. 76.

6. Cfr., de María Zambrano, Delirio y destino, Mondadori, Madrid, 1989, pp. 63-64.

7. Cfr., de María Zambrano, "La experiencia de la historia (Después de entonces)", en Senderos, Anthropos, Barcelona, 1986, p. 17.

8. Cfr. "Notes on "Camp", en http:// pages.zoom.co.uk/leveridge/ sontag.html

9. Citado por Margalit Fox, en The Nere York Times, wrerw.nytimes.com/2004/ 12/28/books/28cnd-sont.html

10. Cfr. Susan Sontag, The New Yorker, 24 de septiembre de 2001, en http:// www.newyorker.com/talk/content/ ?010924ta_talk_wtc 